\title{
Optimization of Water and Nutrient Requirement through Drip Fertigation in Aerobic Rice
}

\author{
Gururaj Kombali ${ }^{1}{ }^{*}$, Nagaraju ${ }^{1}$, B. Rekha ${ }^{1}$, T. Sheshadri ${ }^{1}$, M. N. Thimmegowda ${ }^{1}$ and G. B. Mallikarjuna ${ }^{2}$ \\ ${ }^{1}$ Dept. of Agronomy, College of Agriculture, UAS, GKVK, Bengaluru (560 065), India \\ ${ }^{2}$ Dept. of Agricultural Statistics, College of Agriculture, UAS, GKVK, Bengaluru (560 065), India
}

\section{Article History}

Manuscript No. AR1494a

Received in $21^{\text {st }}$ November, 2015

Received in revised form $31^{\text {st }}$ March, 2016

Accepted in final form $5^{\text {th }}$ April, 2016

\section{Correspondence to}

"E-mail: rajck.kakol@gmail.com

\section{Keywords}

Aerobic rice, drip fertigation, water, nutrient, yield

\begin{abstract}
A field experiment was conducted during Kharif 2012 at Zonal Agricultural Research Station, Bengaluruin red sandy loam soil ( $\mathrm{pH}-6.9$; OC-0.6\%) with medium available nitrogen (348 $\left.\mathrm{kg} \mathrm{ha}^{-1}\right)$, phosphorous (36.13 $\left.\mathrm{kg} \mathrm{ha}^{-1}\right)$ and potassium $\left(244 \mathrm{~kg} \mathrm{ha}^{-1}\right)$ to optimize water and nutrient requirement of aerobic rice (Oryza sativa L.) through drip fertigation. The experiment was laid out in Randomized Complete Block Design (RCBD) with 15 treatments. The variety used was MAS 946-1. Drip fertigation significantly influenced the growth, yield, water productivity and nutrient use efficiency (NUE) in aerobic rice. The results revealed that drip fertigation at 1.5 PE up to maturity with $100 \%$ RDF through water soluble fertilizers (WSF) registered higher water use $(706 \mathrm{~mm})$ and significantly highest water productivity $\left(78.1 \mathrm{~kg}\right.$ ha-cm $\left.{ }^{-1}\right)$ by recording higher grain $\left(6598 \mathrm{~kg} \mathrm{ha}^{-1}\right)$ and straw yield $\left(11084 \mathrm{~kg} \mathrm{ha}^{-1}\right)$ over surface irrigation with soil application of fertilizers (3467 and $5995 \mathrm{~kg} \mathrm{ha}^{-1}$, respectively). Same treatment also noticed higher number of tillers hill ${ }^{-1}$ (48.13) and higher dry matter production ( $118.40 \mathrm{~g} \mathrm{hill}^{-1}$ ) by saving $45 \%$ of irrigation wateras that of surface irrigation. Dripfertigation at $1.5 \mathrm{PE}$ up to maturity with $50 \% \mathrm{RDF}$ through WSF has recorded higher nitrogen $\left(98.3 \mathrm{~kg} \mathrm{~kg}^{-1}\right)$, phosphorus $\left(196.7 \mathrm{~kg} \mathrm{~kg}^{-1}\right)$ and potassium $\left(196.7 \mathrm{~kg} \mathrm{~kg}^{-1}\right)$ use efficiency. However, increased nutrient use efficiency (NUE) was observed with reduced nutrient levels.
\end{abstract}

\section{Introduction}

Rice is most important staple food crop in Asia and it occupies the enviable prime place among the food crops after wheat. Human consumption accounts $85 \%$ of total production for rice and it deserves a special status among cereals as world's most important wetland crop. This global grain provides $20 \%$ of world's dietary energy supply, while wheat and maize supplies 19 and 5\%, respectively (Anon, 2013).

Water and fertilizer are the two basic inputs in irrigated agriculture, while the former is less costly than the later at present. The time is not too far off when water becomes scarce and costlier due to increased industrialisation and intensive agriculture resulting from the increasing food and fibre needs of the burgeoning population round the globe. Efficient utilisation of available water resources is crucial for a country like India, which shares $17 \%$ of the global population with only $2.4 \%$ of land and $4 \%$ of the water resources.

Over the past decade, we have witnessed a growing scarcity and competition for water around the world. As the water demand for domestic, municipal, industrial and environmental purposes rises in the near future, the water availability for agriculture sector gets affected. The estimated water availability for agriculture which is $83.3 \%$ of total water used today, will shrink to $71.6 \%$ in 2025 and to $64.6 \%$ in 2050 (Yadav, 2002).

Fertilizer application in wetland rice farming is currently done manually through the soil application in split doses. The technique employed is imprecise and causes problems such as fluctuating nutrient supply and uneven fertilizer spread. It is labour intensive and makes use of expensive fertilizers. This leads to various losses of nutrients under submerged cultivation. Besides loss of water and fertilizers through seepage and percolation, impounding water in paddy fields has an important environmental impact by contributing to global warming through considerable emission of methane.

With this background, an investigation was carried out to optimize the water and nutrient requirement of aerobic rice 
through drip fertigation.

\section{Materials and Methods}

The field experiment was conducted at the Zonal Agricultural Research Station, University of Agricultural Sciences, GKVK, Bengaluru and Karnataka during Kharif 2012. The soil was redsandy clay loam in nature and near neutral in reaction ( $\mathrm{pH}: 6.9$ ) and organic carbon (OC) content was high $(0.60 \%)$. The soil test results ofthe experimental site reveal that soil is medium in nitrogen, phosphorus andpotassium, respectively. The average annual rainfall of site is around $926 \mathrm{~mm}$. The field experiment was laid out in a Randomized Complete Block Design (RCBD) with three replications. Treatment details are as follows; $\mathrm{T}_{1}$ : Surface irrigation with soil application of $\mathrm{RDF}^{*}, \mathrm{~T}_{2}$ : Drip irrigation (1.5 $\left.\mathrm{PE}^{* *}\right)$ with soil application of $100 \% \mathrm{RDF}, \mathrm{T}_{3}$ : Drip irrigation $(1.0+1.5$ $\mathrm{PE}$ ) with soil application of $100 \% \mathrm{RDF}, \mathrm{T}_{4}$ : Drip fertigation (1.5 PE) with $100 \%$ RDF through $\mathrm{NF}^{\#}, \mathrm{~T}_{5}$ : Drip fertigation (1.5 PE) with $75 \%$ RDF through NF, $\mathrm{T}_{6}$ : Drip fertigation (1.5 $\mathrm{PE})$ with $50 \% \mathrm{RDF}$ through $\mathrm{NF}, \mathrm{T}_{7}$ : Drip fertigation $(1.0+1.5$ PE) with $100 \%$ RDF through NF, $\mathrm{T}_{8}$ : Drip fertigation $(1.0+1.5$ $\mathrm{PE}$ ) with $75 \% \mathrm{RDF}$ through $\mathrm{NF}, \mathrm{T}_{9}$ : Drip fertigation $(1.0+1.5$ $\mathrm{PE}$ ) with $50 \% \mathrm{RDF}$ through $\mathrm{NF}, \mathrm{T}_{10}$ : Drip fertigation (1.5) with $100 \%$ RDF through $\mathrm{WSF}^{\#}, \mathrm{~T}_{11}$ : Drip fertigation (1.5) with $75 \%$ RDF through WSF, $\mathrm{T}_{12}$ : Drip fertigation (1.5) with $50 \%$ RDF through WSF, $\mathrm{T}_{13}$ : Drip fertigation (1.0+1.5 PE) with $100 \%$ RDF through WSF, $\mathrm{T}_{14}$ : Drip fertigation $(1.0+1.5$ $\mathrm{PE})$ with $75 \% \mathrm{RDF}$ through $\mathrm{WSF}, \mathrm{T}_{15}$ : Drip fertigation $(1.0+1.5 \mathrm{PE})$ with $50 \%$ RDF through WSF.

\subsection{Irrigation and fertilizer application}

The irrigation was given through PVC pipe after filtering throughthe screen filter by $7.5 \mathrm{HP}$ motor from the bore well. Thepressure maintained in the system was $1.2 \mathrm{~kg} \mathrm{~cm}^{-2}$. From thesub main, in-line laterals of $16 \mathrm{~mm}$ were laid at a spacing of $0.5 \mathrm{~m}$ with $4 \mathrm{lph}$ discharge rate emitters positioned at a distance of $40 \mathrm{~cm}$. Drip irrigation was scheduled based on the open panevaporation as per the treatment requirement after subtractingeffective rainfall for that period. However, surface irrigation was scheduled based on recommended package of practices.

At the time of sowing, FYM was applied to all the treatments at the rate of $10 \mathrm{t} \mathrm{ha}^{-1}$. Fertilizers were applied as per thetreatment details. The soil application was done as per therecommendation. Out of total nutrients, $50 \% \mathrm{~N}$ and theentire dose of $\mathrm{P}_{2} \mathrm{O}_{5}$ and $\mathrm{K}_{2} \mathrm{O}$ were applied as basal and remaining $50 \% \mathrm{~N}$ in two equal splits at 30 and 60 days after sowing (DAS), respectively. However, drip fertigation was given in eight equal splits ateight days interval as per treatment requirement. The fertilizers used for fertigation are
Urea, DAP and MOP .The fertilizer recommendation for the crop is 100:50:50 kg NPK ha-1.

The direct sowing was done at $5 \mathrm{~cm}$ depth with $25 \times 25 \mathrm{~cm}^{2}$ spacing. The experiment was maintained as per the standard package of practice of aerobic rice cultivation (Anon, 2007). To overcome border effect observations were made on middleplants in the row. The observations were recorded inexperiments on five random plants at centre of the row forgrowth and yield attributing characters. Numbers of tillers were noted by counting from the sampling unit and was expressed on tillers hill ${ }^{-1}$. Five hills were selected for recording total dry matter production by aerobic rice. These plants were then air dried and further dried in a hot air oven at $62{ }^{\circ} \mathrm{C}$ till constant weight was obtained. Dry weight was recorded and was expressed on grams hill ${ }^{-1}$ basis. Crop was harvested at maturity and harvested plants were dried for 3-4 days to bring down moisture content to around 14\%. After threshing, seeds were cleaned, sun dried and their weight was recorded. Separated straw was also weighed and both grain and straw yields in $\mathrm{kg}$ plot $^{-1}$ were converted to $\mathrm{kg} \mathrm{ha}^{-1}$. Irrigation water given was recorded based on pan evaporation values and discharge capacity of emitters. Effective rainfall for the cropping period is summed up with irrigation water applied to get total water used for crop production. Water productivity of aerobic rice under different treatments was worked out as:

Water productivity $\left(\mathrm{kg}\right.$ ha- $\left.\mathrm{cm}^{-1}\right)=$ Grain yield $\left(\mathrm{kg} \mathrm{ha}{ }^{-1}\right) /$ Quantity of total water applied (cm)

Nutrient use efficiency (NUE) for nutrients like nitrogen, phosphorus and potassium was worked out by using following formula and expressed as $\mathrm{kg} \mathrm{kg}^{-1}$ :

$\mathrm{NUE}=\left[\right.$ Grain yield $\left(\mathrm{kg} \mathrm{ha}^{-1}\right) /$ Nutrient applied $\left.\left(\mathrm{kg} \mathrm{kg}^{-1}\right)\right] 100$

The data obtainedwere subjected to statistical analysis given by Gomez and Gomez (1984). Least significant difference (LSD) values at $p=0.05$ were used to interpret the treatment differences.

\section{Results and Discussion}

\subsection{Effect on water use and water productivity}

The results from the study reveals that drip fertigation at 1.5 $\mathrm{PE}$ up to maturity with $100 \% \mathrm{RDF}$ through WSF recorded higher water productivity of $78.1 \mathrm{~kg}$ ha- $\mathrm{cm}^{-1}$ besides saving $39 \%$ of water as compared to surface irrigation (Table 1). Total water use was registered with surface irrigation method $(1288.0 \mathrm{~mm})$ followed by treatments having irrigation levels at $1.5 \mathrm{PE}$ up to maturity $(844.4 \mathrm{~mm})$ and least total water used was with 1.0 PE up to tillering and 1.5 PE up to maturity $(766.4 \mathrm{~mm})$. The increase in water productivity in all drip 


\begin{tabular}{|c|c|c|c|c|c|}
\hline Sl. no. & Treatments & $\begin{array}{l}\text { Irrigation water } \\
\text { used }(\mathrm{mm})\end{array}$ & $\begin{array}{l}\text { Total water use } \\
\mathrm{I}_{\mathrm{R}}+\mathrm{E}_{\mathrm{R}}(\mathrm{mm})\end{array}$ & 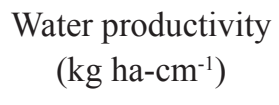 & $\begin{array}{c}\% \text { water } \\
\text { saved }\end{array}$ \\
\hline 1. & $\begin{array}{l}\text { Surface irrigation with soil application of } \\
\text { RDF }\end{array}$ & 1150 & 1288.0 & 26.9 & - \\
\hline 2. & $\begin{array}{l}\text { Drip irrigation (1.5 PE) with soil application } \\
\text { of RDF }\end{array}$ & 706 & 844.4 & 54.1 & 38.6 \\
\hline 3. & $\begin{array}{l}\text { Drip irrigation (1.0+1.5PE) with soil } \\
\text { application of RDF }\end{array}$ & 628 & 766.4 & 56.4 & 45.4 \\
\hline 4. & $\begin{array}{l}\text { Drip fertigation (1.5 PE) with } 100 \% \text { RDF } \\
\text { through NF }\end{array}$ & 706 & 844.4 & 64.6 & 38.6 \\
\hline 5 & $\begin{array}{l}\text { Drip fertigation }(1.5 \mathrm{PE}) \text { with } 75 \% \mathrm{RDF} \\
\text { through NF}\end{array}$ & 706 & 844.4 & 60.9 & 38.6 \\
\hline 6. & $\begin{array}{l}\text { Drip fertigation }(1.5 \mathrm{PE}) \text { with } 50 \% \mathrm{RDF} \\
\text { through NF}\end{array}$ & 706 & 844.4 & 56.9 & 38.6 \\
\hline 7. & $\begin{array}{l}\text { Drip fertigation }(1.0+1.5 \mathrm{PE}) \text { with } 100 \% \\
\text { RDF through NF }\end{array}$ & 628 & 766.4 & 63.0 & 45.4 \\
\hline 8. & $\begin{array}{l}\text { Drip fertigation }(1.0+1.5 \mathrm{PE}) \text { with } 75 \% \\
\text { RDF through NF }\end{array}$ & 628 & 766.4 & 61.7 & 45.4 \\
\hline 9. & $\begin{array}{l}\text { Drip fertigation (1.0+1.5 PE) with } 50 \% \\
\text { RDF through NF }\end{array}$ & 628 & 766.4 & 60.1 & 45.4 \\
\hline 10. & $\begin{array}{l}\text { Drip fertigation (1.5 PE) with } 100 \% \text { RDF } \\
\text { through WSF }\end{array}$ & 706 & 844.4 & 78.1 & 38.6 \\
\hline 11. & $\begin{array}{l}\text { Drip fertigation (1.5 PE) with } 75 \% \text { RDF } \\
\text { through WSF }\end{array}$ & 706 & 844.4 & 64.7 & 38.6 \\
\hline 12. & $\begin{array}{l}\text { Drip fertigation }(1.5 \mathrm{PE}) \text { with } 50 \% \mathrm{RDF} \\
\text { through WSF }\end{array}$ & 706 & 844.4 & 58.2 & 38.6 \\
\hline 13. & $\begin{array}{l}\text { Drip fertigation }(1.0+1.5 \mathrm{PE}) \text { with } 100 \% \\
\text { RDF through WSF }\end{array}$ & 628 & 766.4 & 70.0 & 45.4 \\
\hline 14. & $\begin{array}{l}\text { Drip fertigation }(1.0+1.5 \mathrm{PE}) \text { with } 75 \% \\
\text { RDF through WSF }\end{array}$ & 628 & 766.4 & 66.9 & 45.4 \\
\hline 15. & $\begin{array}{l}\text { Drip fertigation }(1.0+1.5 \text { PE) with } 50 \% \\
\text { RDF through WSF }\end{array}$ & 628 & 766.4 & 61.7 & 45.4 \\
\hline \multicolumn{2}{|l|}{$\mathrm{SEm} \pm$} & NA & NA & 4.6 & NA \\
\hline \multicolumn{2}{|c|}{$\operatorname{LSD}(p=0.05)$} & NA & NA & 13.6 & NA \\
\hline
\end{tabular}

RDF: Recommended dose of fertilizers; PE: Pan evaporation; NA: Not analysed; NF: Normal fertilizers; WSF: Water soluble fertilizer; IR: Irrigation requirement; ER: Effective rainfall; 1.5 PE: 1.5 PE up to maturity; 1.5 PE: 1.0 PE up to tillering and $1.5 \mathrm{PE}$ tillering to maturity

irrigated treatments over surface irrigation was mainly due to considerable saving of irrigation water, greater increase in yield of crop and higher nutrient use efficiency. This was in accordance with Chawla and Narda, 2001. These studies reveal that supplying water to soil and nearer to the plant without much loss of water resulting in higher water productivity.

\subsection{Effect on growth attributes}

Growth attributes like total number of tillers and total dry matter production were significantly affected by drip fertigation (Table 2). Drip fertigation at $1.5 \mathrm{PE}$ up to maturity with $100 \%$ RDF through WSF recorded significantly higher number of total tillers (48.13 hill-1 ${ }^{-1}$ ) and produced higher dry matter hill-1 $(118.40 \mathrm{~g})$ than other treatments. This is mainly 
because of WSF through fertigation resulted in continuous supply of nutrients besides maintaining optimum water availability which lead to higher uptake of nutrients which in turn recorded higher growth attributes. Similar results have been obtained by Veeraputhiran et al. (2002); Vijay kumar (2009). Effect on yield attributes and yield
Drip fertigation significantly influenced the yield attributes of aerobic rice. Drip fertigation at 1.5 PE up to maturity with $100 \%$ RDF through WSF recorded higher productive tillers $\left(27.77\right.$ hill $\left.^{-1}\right)$ panicle length $(26.17 \mathrm{~cm})$, panicle weight $(3.21 \mathrm{~g})$, grains panicle ${ }^{-1}(170.80)$ and test weight of grains $(25.33 \mathrm{~g})$. Significantly higher grain and straw yield (Table

\begin{tabular}{|c|c|c|c|c|c|c|c|c|c|}
\hline Trts. & $\begin{array}{c}\text { Total tillers } \\
\text { hill }^{-1}\end{array}$ & $\begin{array}{c}\text { TDMP } \\
\left(\mathrm{g} \mathrm{hill}^{-1}\right)\end{array}$ & $\begin{array}{l}\text { Productive } \\
\text { tillers hill }^{-1}\end{array}$ & $\begin{array}{c}\text { Grains } \\
\text { panicle }^{-1}\end{array}$ & $\begin{array}{c}\text { Panicle } \\
\text { length }(\mathrm{cm})\end{array}$ & $\begin{array}{c}\text { Panicle } \\
\text { weight }(\mathrm{g})\end{array}$ & $\begin{array}{c}\text { Test } \\
\text { weight }(\mathrm{g})\end{array}$ & $\begin{array}{c}\text { Grain yield } \\
\left(\mathrm{kg} \mathrm{ha}^{-1}\right)\end{array}$ & $\begin{array}{c}\text { Straw yield } \\
\left(\mathrm{kg} \mathrm{ha}^{-1}\right)\end{array}$ \\
\hline 1. & 33.07 & 81.30 & 17.63 & 135.23 & 18.70 & 3.00 & 19.73 & 3467 & 5995 \\
\hline 2. & 38.10 & 88.10 & 23.73 & 156.19 & 21.43 & 3.28 & 21.03 & 4567 & 7632 \\
\hline 3. & 35.33 & 84.54 & 17.87 & 144.10 & 19.70 & 3.20 & 20.00 & 4319 & 6640 \\
\hline 4. & 41.65 & 114.15 & 25.13 & 167.62 & 24.93 & 3.97 & 23.67 & 5451 & 8704 \\
\hline 5. & 38.27 & 108.45 & 22.07 & 167.40 & 22.67 & 3.50 & 22.67 & 5141 & 8549 \\
\hline 6. & 38.17 & 104.15 & 21.10 & 163.94 & 22.33 & 3.42 & 22.20 & 4800 & 7899 \\
\hline 7. & 39.30 & 106.45 & 21.07 & 164.92 & 23.50 & 3.58 & 22.30 & 4831 & 8166 \\
\hline 8. & 38.27 & 101.55 & 19.10 & 162.48 & 22.27 & 3.31 & 22.20 & 4731 & 7910 \\
\hline 9. & 38.07 & 95.80 & 18.63 & 161.12 & 21.50 & 3.21 & 21.20 & 4603 & 6789 \\
\hline 10. & 48.13 & 118.40 & 27.77 & 170.80 & 26.17 & 4.23 & 25.33 & 6598 & 11084 \\
\hline 11. & 45.80 & 114.90 & 26.97 & 165.09 & 25.33 & 4.04 & 24.50 & 5470 & 9680 \\
\hline 12. & 39.30 & 111.60 & 26.30 & 158.51 & 24.23 & 3.88 & 23.67 & 4917 & 8885 \\
\hline 13. & 44.23 & 113.48 & 23.97 & 163.37 & 26.07 & 4.00 & 24.43 & 5365 & 9168 \\
\hline 14. & 41.30 & 111.38 & 22.27 & 159.84 & 23.83 & 3.74 & 23.93 & 5131 & 8741 \\
\hline 15. & 38.83 & 109.80 & 21.87 & 156.16 & 23.47 & 3.42 & 23.00 & 4731 & 8235 \\
\hline $\mathrm{SEm} \pm$ & 2.54 & 1.47 & 1.62 & 4.48 & 1.50 & 0.25 & 0.58 & 389 & 753 \\
\hline $\begin{array}{l}\text { LSD } \\
(p=0.05)\end{array}$ & 7.36 & 4.25 & 4.70 & 12.97 & 4.37 & 0.75 & 1.68 & 1129 & 2182 \\
\hline
\end{tabular}

TDMP : Total dry matter production

2) was recorded in drip fertigation at $1.5 \mathrm{PE}$ up to maturity with 100\% RDF through WSF (6598 and $11084 \mathrm{~kg} \mathrm{ha}^{-1}$, respectively) which was $90.3 \%$ higher than surface irrigation with soil application of 100\% RDF (3467 and $5995 \mathrm{~kg} \mathrm{ha}^{-}$ ${ }^{1}$, respectively) which was significantly lower and recorded 45.83 and $41.85 \%$ lower grain yield as compared to drip fertigation at $1.5 \mathrm{PE}$ up to maturity with $50 \% \mathrm{RDF}$ through WSF (4917 $\mathrm{kg} \mathrm{ha}^{-1}$ ) or NF (4800 kg ha-1). The increase in the yield is related to higher leaf area index and crop growth rate which are contributed for assimilation of more photosynthates and resulted in superior yield attributes and yield. Such findings are in consonance with the findings of Muralidhar (1998); Latif (2001); Ali et al. (2005).

\subsection{Effect on nutrient uptake and nutrient use efficiency}

Depending upon the varied amount of nutrient supply through drip fertigation and corresponding grain and straw yield, nutrient uptake nutrient use efficiency for elements like nitrogen, phosphorus and potassium showed significant difference, which is presented in Table 3. Drip fertigation at $1.5 \mathrm{PE}$ up to maturity with $100 \% \mathrm{RDF}$ through WSF shown higher nutrient uptake $(142.58,36.05$ and $92.59 \mathrm{~kg}$ $\mathrm{ha}^{-1}$, respectively) wherein drip fertigation at $1.5 \mathrm{PE}$ up to maturity with $50 \%$ RDF through WSF registered higher NUE for $\mathrm{N}, \mathrm{P}$ and $\mathrm{K}$ (98.3, 196.7 and $196.7 \mathrm{~kg} \mathrm{~kg}^{-1}$, respectively) as compared to other treatments and also there was increased nutrient use efficiency with decrease in the nutrient levels. Also, water soluble fertilizers have given higher use efficiency of nutrients as compared to normal fertilizers with drip fertigation at 1.5 PE up to maturity. This was attributed to better availability of moisture and nutrients throughout crop growth stages in drip fertigation system leading to better uptake of nutrients, production of higher dry matter and in turn economic yield. This indicated that increased solubility resulted in improved uptake with lesser losses, even when lower doses of nutrients are applied as compared to higher 
Table 3: Influence of drip fertigation on nutrient uptake and nutrient use efficiency of aerobic rice

\begin{tabular}{|c|c|c|c|c|c|c|}
\hline \multirow[t]{2}{*}{ Trts. } & \multicolumn{3}{|c|}{$\begin{array}{l}\text { Nutrient uptake } \\
\qquad\left(\mathrm{kg} \mathrm{ha}^{-1}\right)\end{array}$} & \multicolumn{3}{|c|}{$\begin{array}{l}\text { Nutrient use efficiency } \\
\qquad\left(\mathrm{kg} \mathrm{kg}^{-1}\right)\end{array}$} \\
\hline & $\begin{array}{l}\text { Nitro- } \\
\text { gen }\end{array}$ & $\begin{array}{l}\text { Phosp- } \\
\text { horus }\end{array}$ & $\begin{array}{l}\text { Potas- } \\
\text { sium }\end{array}$ & $\begin{array}{l}\text { Nitro- } \\
\text { gen }\end{array}$ & $\begin{array}{l}\text { Phosp- } \\
\text { horus }\end{array}$ & $\begin{array}{l}\text { Potas- } \\
\text { sium }\end{array}$ \\
\hline 1. & 104.17 & 25.08 & 64.40 & 34.7 & 69.3 & 69.3 \\
\hline 2. & 116.17 & 29.29 & 71.34 & 45.7 & 91.3 & 91.3 \\
\hline 3. & 112.17 & 27.91 & 67.96 & 43.2 & 86.4 & 86.4 \\
\hline 4. & 126.97 & 34.84 & 80.87 & 54.5 & 109.0 & 109.0 \\
\hline 5. & 123.77 & 33.97 & 78.20 & 68.6 & 137.1 & 137.1 \\
\hline 6. & 118.17 & 32.76 & 74.35 & 96.0 & 192.0 & 192.0 \\
\hline 7. & 122.83 & 33.11 & 78.12 & 48.3 & 96.6 & 96.6 \\
\hline 8. & 120.70 & 31.55 & 75.15 & 63.1 & 126.2 & 126.2 \\
\hline 9. & 118.17 & 30.33 & 72.27 & 92.1 & 184.1 & 184.1 \\
\hline 10. & 142.58 & 36.05 & 92.59 & 65.9 & 131.9 & 131.9 \\
\hline 11. & 137.17 & 34.93 & 89.17 & 72.9 & 145.8 & 145.8 \\
\hline 12. & 130.97 & 33.80 & 82.52 & 98.3 & 196.7 & 196.7 \\
\hline 13. & 136.57 & 34.84 & 84.89 & 53.7 & 107.3 & 107.3 \\
\hline 14. & 128.77 & 33.80 & 81.97 & 68.4 & 136.8 & 136.8 \\
\hline 15. & 124.37 & 33.11 & 80.26 & 94.6 & 189.2 & 189.2 \\
\hline $\operatorname{SEm} \pm$ & 1.71 & 0.82 & 0.29 & 5.9 & 11.9 & 11.9 \\
\hline $\begin{array}{l}\text { LSD } \\
(p= \\
0.05)\end{array}$ & 4.96 & 2.40 & 0.84 & 17.3 & 34.7 & 34.7 \\
\hline
\end{tabular}

levels. Such findings are in consonance with the findings of Muralidhar (1998); Latif (2001); Ali et al. (2005); Raina et al. (2011).

\section{Conclusion}

This indicated that drip fertigation at $1.5 \mathrm{PE}$ up to maturity with $100 \%$ RDF through WSF will be the best treatment in getting higher growth and yield apart from higher water productivity. There could be a possibility of saving $50 \%$ fertilizer through drip fertigation by achieving comparable yield as that of $100 \%$ RDF. Further which is significantly higher as compared to surface irrigation with $100 \% \mathrm{RDF}$ through soil application.

\section{References}

Ali, A., Zia, M.S., Hussain, F.,Salim, M., 2005, Efficacy of different methods of potassium fertilizer application on paddy yield, $\mathrm{K}$ uptake and agronomic efficiency, Pakistan Journal of Agricultural Sciences 42(1-2), 27-32.

Ali, A., Zia, M.S., Hussain, F., Salim, M., 2005, Efficacy of different methods of potassium fertilizer application on paddy yield, $\mathrm{K}$ uptake and agronomic efficiency, Pakistan Journal of Agricultural Sciences 42(1-2), 27-32.

Anonymous, 2007, A new aerobic variety. University ofAgricultural Sciences, GKVK, Bangalore, India, 13-16.

Anonymous, 2013, Rice is life, Food and agricultural organization of United Nations, 11-23.

Chawla, J.K., Narda, N.K., 2001, Economy in water and fertilizer use in trickle fertigated potato. Irrigation and Drainage 50, 129-137.

Gomez, K.A., Gomez, A.A., 1984. Statistical procedures for agricultural research. Second Edition. John Wiley \& Sons, New York, USA.

Latif, A., 2001, Effect of fertigation applied nitrogen and phosphorus on yield and composition of maize.Pakistan Journal of Soil Science 19(1-2), 23-26.

Muralidhar, A.P., 1998, Effect of fertigation with normal and water soluble fertilizer compared to drip and furrow systems in capsicum-maize-sunflower cropping sequence. Ph.D. Thesis, University of Agricultural Sciences, Bangalore.

Raina, J.N., Tarika, S., Shashi, S., 2011, Effect of drip fertigation with different fertilizers on nutrient distribution in soil, leaf nutrient content and yield of apricot., Journal of Indian Society of Soil Science 59(3), 268-277.

Veeraputhiran, R., Kandasamy, O.S., Sunder Singh, S,D., 2002, Effect of drip irrigation and fertigation on growth and yield of hybrid cotton. Journal of Agricultural Resource Management 1(20), 88-97.

Vijaykumar, P., 2009, Optimization of water and nutrient requirement for yield maximization in hybrid rice under drip fertigation system rice (Oryza sativa L.). M.Sc. (Agri.) Thesis, Tamil Nadu Agricultural University, Coimbatore.

Yadav, J.S.P., 2002, Conservation and managing water resource for sustainable agriculture. Journal of Water Management 10(1-2), 1-10. 